\title{
KONSEP HARTA DAN KEPEMILIKAN DALAM PRESPEKTIF ISLAM
}

\author{
EKONOMI DAN BISNIS ISLAM UNIVERSITAS ISLAM NEGERI \\ ALAUDDIN MAKASSAR
}

Ahmad Junaedi T

90500118073

Ajunaedi335@gmail.com

\begin{abstract}
Islam views property in essence as the property of Allah. However, Allah has handed over the management of these assets to humans as caliphs on earth, so one's acquisition of the property is the same as the activities carried out by a person to utilize and develop assets. Because, when a person owns property, his essence is that he owns the property only to be used and bound by the syara' laws, not being free to manage it absolutely. Therefore, it is necessary to have rules that regulate human needs so as not to violate and control the rights of others, especially those related to property and ownership in Islam.
\end{abstract}

Keywords: Wealth, Milk, Shari'ah

\section{Abstrak}

Islam memandang harta pada hakikatnya adalah hak milik Allah. Akan tetapi Allah telah menyerahkan pengelolaan atasharta tersebut kepada manusia sebagai khalifah di muka bumi, maka perolehan seseorang terhadap harta itu sama dengan kegiatan yang dilakukan oleh seseorang untuk memanfaatkan serta mengembangkan harta. Sebab, ketika seseorang memiliki harta, maka esensinya dia memiliki harta tersebut hanya untuk dimanfaatkan dan terikat dengan 
hukum-hukum syara', bukan bebas mengelola secara mutlak. Oleh sebab itu perlu adanya aturan-aturan yang mengatur kebutuhan manusia agar tidak melanggar dan menguasai hak orang lain, khususnya terkait dengan harta dan kepemilikan dalam Islam.

Kata Kunci: Harta, Milk, Syari'ah

\section{PENDAHULUAN}

Manusia sebagai makhluk sosial pada prinsipnya selalu ingin hidup bermasyarakat. Dalam kehidupan bermasyarakat, manusia akan menghadapi berbagai macam persoalan untuk menutupi kebutuhan antara yang satu dengan yang lain, sehingga dibutuhkan sikap saling tolong-menolong. Setiap individu pada dasarnya mengalami ketergantungan pada nilai-nilai kemanusiaan dan keberadaanya dalam suatu kelompok.

Ketergantungan seseorang dikarenakan setiap manusia mempunyai kebutuhan. Kebutuhan yang harus dipenuhi oleh ekonomi itu berbeda dari masyarakat yang satu ke masyarakat yang lain, dari orang yang satu ke orang yang lain. Perbedaan itu disebabkan oleh berbagai faktor,salah satunya sesuai kebutuhan.2Ajaran Islam merupakan ajaran yang sempurna mencakup seluruh kehidupan maka kita wajib berpendirian bahwa Islam sebagai agama yang telah menggariskan prinsip-prinsip kehidupan mencakup berbagai aspek, termasukaspek ekonomi. (Leli, 2019)

Islam mempunyai corak ekonomi sendiri, berdiri sendiri dan berbeda dengan kapitalisme. Perbedaan itu terlihat dalam praktek sistem ekonomi kapitalis yang tujuan utamanya untuk memperoleh keuntungan material, sehingga muncul egoisme, monopoli, dan usaha mengumpulkan harta kekayaan semata.3Islam memelihara keseimbangan antara hak milik pribadi dan kolektif sehingga Islam menjamin pembagian kekayaan yang seluas-luasnya dan paling bermanfaat 
melalui lembaga-lembaga yang didirikan.4permasalahannya banyak yang belum memahami bagaimana Islam memandang harta dan kepemilikan.

Harta dalam bahasa arab disebut al-mal atau jamaknnya al-amwal. Harta (al-mal) menurut kamus Al-muhithtulisan Alfairuz Abadi, adalah

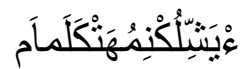

ma malakatahu min kulli syai (segala sesuatu yang engkau punyai).

Sedangkan harta menurut istilah syariah adalahsetiap-tiap apa yang dapat dimanfaatkan menurut cara-cara yang dibenarkan syariah, seperti jual beli, sewa menyewa, pinjam meminjam, pemanfaatan (konsumsi), dan hibah.6Nasrun Haroen menjelaskan harta adalah segala yang diminati manusia dan dapat dihadirkan ketika diperlukan, atau segala sesuatu yang dapat dimiliki, disimpan dan dapat dimanfaatkan.

Dalam kontekshistoris,Islam sebagai ajaran yangtelah menempuhperjalanan panjang dan tidak terlepasdari sebuah sistem perekonomian, sebagaimana yang telahdijalankan oleh Rasulullah saw, sejak kecilRasulullah diasuh pamannya Abu Thalib. Merekamenjalankan bisnisberdagang diberbagai daerah jazirah Arab, kemudian rasulullah saw melakukan hubungan kerjasamadengan Sitti Khadijah, baik sebelum menikahi Sitti Khadijah maupun sesudah menikahinya. Dalam sejarah rasulullah saw mempunyaimodal dasar dalam berdagangyaitu kejujuran (al-shiddiq)dan kepercayaan (amanah), sehingga rasa simpatitimbul dalam diri pribadi konsumen terhadap Rasulullah saw. Semua itu dapat dilihat dengan keuntungan yang dia capai dalam rentan waktu yangsingkat. Tanpa harus menghindari pesaingnya. (Alis, 2019)

Hampir setiap kegiatan manusia merupakan bagian dari sistem bisnis. Setiap kegiatan yang dilakukannya sudah tentu merupakan perwujudan dari aktivitas bisnis. Seorangpetani yang mengolah sawah, menggiling padi, menjual beras, semua itu merupakan aktivitas bisnis. Pada bidang jasa, dokter melayani pasien, Perusahaan Listrik Negara (PLN) melayani penerangan masyarakat, Perguruan Tinggi mendidik mahasiswa, dan perusahaanjaringan tenaga kerja Indonesia (PJTKI) yang menyalurkan tenaga kerja merupakan perwujudan aktivitas bisnis.

Untuk itu Islam menekankan adanya penyebaran harta kekayaan sehinggamenghindari dari perbuatan dosa tersebut. Dimana penyebaran harta 
kekayaantersebut kesemua bagian untuk menjaga keutuhannya dan mencegahpenimbunan harta.Dengan demikian Islam memberikan suatu landasanadanya suatu sistemekonomi yang diterapkan dengan carayang sangat mudahuntuk memberikaninisiatif individu, pemberian hak milik, tetapi harus adabatasan-batasan yangmembantu pembentukan keseimbangan secarabenarantara individu dan umum.

Dilihat dari kondisisistemperekonomi yang telah berkembang saat inimerupakan dua sistemekonomi yang paling berpengaruh di dunia yaitu sistemekonomi kapitalis dan sistem ekonomi sosialis.Pada gilirannya,sistemekonomi yang dianut olehsekelompok manusia sesungguhnya berfungsi untukmencapai tujuan atau hasiltertentu yang memiliki nilai yang ditetapkan danbergantung pada prioritasmasyarakat atau negara penganut sistem tersebut.Sistemekonomi kapitalis lebihmemprioritaskan individu daripada kelompok,sedangkan sistem ekonomisosialis lebih memprioritaskan kepentingan negaradaripada kepentingan individu.8Dari sini muncul masalah ekonomi, menurutmazhab Baqir berpendapatbahwa hal ini muncul karena adanya distribusi yang tidak merata dan adilsebagai akibat sistem ekonomi yang membolehkaneksploitasi pihak yang kuat terhadap pihak yang lemah. (Sularno, 2013)

Hal ini mengakibatkan adanya penguasaan hakindividu danmengesampingkan hak umum, sehingga yang kuat memiliki aksesterhadapsumber daya akibatnya menjadi sangat kaya, sementara yang lemahtidakmemiliki akses terhadap sumber daya akibatnya menjadi sangat miskin.Olehkarena itu masalah ekonomi muncul bukan karena sumberdaya yangterbatastetapi karena keserakahan manusia yang tidak terbatas.

Pemilik sesungguhnya dari sumber daya yang ada adalah Allah SWT, manusia dalam hal ini hanya penerima titipanuntuk sementara saja. Sehingga sewaktuwaktu dapat di ambil kembali oleh Allah SWT. Oleh sebab itu kepemilikan mutlak atas harta tidak di akui dalam Islam. Untuk menjaga keperluan masingmasing perlu ada aturan-aturan yang mengatur kebutuhan manusia danagar manusia itu tidak melanggar hak orang lain. Maka, timbullah hak dan kewajiban diantara sesama manusia.Masalah kepemilikan sekarang ini masih menjadi perselisihan. Ada yang menganggap milik nasional dan masyarakat harus mengakui bahwa pemerintah lah yangmemiliki semua sumber. Ada juga yang 
memperlakukan sebagai milik perorangan, sehingga setiap orang bisa menikmati kebebasan hak memiliki.

Kepemilikan sebagai persoalan ekonomi mendapat perhatiaan yang cukup besar dalam islam. Pada dasarnya, kepemilikan merupakan pokok persoalan dalam aktivitas ekonomi manusia. Secara teologis, kepemilikan yang hakiki berada di tangan Allah. Manusia hanya di beri kesempatan untuk menjalankan dalam bentuk amanat. Islam menggariskanbahwa kepemilikan senantiasa dipahami dalam dunia dimensi, kepemilikan umum, dan khusus. Kepemilikan umum berkaitan dengan karakter manusia sebagai makhluk sosial, sedangkan kepemilikan khusus merupakan pengejawantahan sebagai makhluk individu. Manusia harus diberikan ruang yang sama untuk mengaksessumber kekayaan umum. Tidak ada pembedaan hirarkhis mengingat manusia mempunyai kedudukan sama dihadapan Tuhan. Hanya ketakwaan, dan kepatuhan terhadap demarkasi ketetapan Tuhan yaqng membedakan manusia. Dalam hal ini, kreativitas dan kapasitas personal memiliki peran penentu dalam mewujudkan kesejahteraan dari usaha pemanfaatan kekayaan alam yang telah disediakan oleh Tuhan.

Karakter makhluk sosial bukanlah hal dominan yang berkembang dalam diri manusia. Pada saat tertentu, manusia menunjukkan sisi lainnya yaitu sikap egois dan tidak memperdulikan orang lain yang merupakan pengejawantahan sisi sebagai makhluk hidup. Bahkan dalam batas-batas tertentu, manusia dapat saling menjatuhkan dan menyingkirkan orang lain. Sebagai perimbangan, harus ada institusi sosial yang mengatur dan memberikan regulasi dalam relasi sosial. (Murlan, 2011)

Dalam sistem kapitalis, individu merupakan poros perputaran ekonomi. Individu merupakan penggerak sekaligus tujuan akhir aktivitas ekonomi tersebut. Negara tidak berhak mengatur individu, bahkan Negara harus memberikan kebebasan seluas-luasnya kepada individu. Individu bebas melaksanakan aktivitas ekonomi dan berbuat sesuka hati, baik itu mendatangkan laba atau sebaliknya. Mereka tidak peduli apakah tindakan mereka ini menimbulkan danpak positif maupun dampak negative bagi masyarakat.

Faktor pendorong adanya kebebasan tanpa batas antara lain : 
a.Pandangan terhadap eksistensi individu sebagai pusat dunia dan tujuan yang akan diraih

.b.Adanya tujuan untuk merealisasikan tujuan kekuasaan terbesar bagi kepentingan individu, dengan pertimbangan bahwa kepentingan umum dinyatakan sebagai kumpulan kepentingan-kepentingan individu

.c.Urgensi kebebasan ekonomi tanpabatas dan persaingan sempurna yang diharapkan akan memberikan jaminan kebutuhan para konsumen.Kelemahan sistem kapitalis :

a.Munculnya kesenjangan perimbangan dalam distribusi kekayaan antar individu, dan sarana-sarana produksi hanya akan terkumpul pada satu kelompok. Pengaruh semangat materialis akan membagi masyarakat ke dalam dua kelompok, golongan kaya dan golongan miskin.

b.Timbulnya krisis dan merajalelanya kejahatan karena meningkatnya pengangguran yang diakibatkan banyaknya produsen yang berhenti berproduksi dan menutup pabrik. Hal ini disebabkan karena produsen komoditas berbagai kebutuhan mewah tertentu meningkat demi memenuhi kebutuhan-kebutuhan pemilik modal besar, dan langkah ini memaksa pasar untuk menyerapnya

c.Meningkatnya praktek monopoli secara empiris-aplikatif dan yuridis sebagai bagian dari usaha untuk melemahkan samangat persaingan. Regulasi-regulasi monopoli dan semi sering di tujukan untuk mengeruk keuntunghan yang masih deapat diraih dengan jalan aturan hukum dalam produksi dan diaya (cost) melalui strategi penguatan aturan-aturan produksi. Banyak pihyak dengan sengaja menghancurkan bahan produksi dan melarang bidang pertanian atau bidang bsolute beberapa komoditi tertentu untuk menghancurkan harga.

d.Kerbebasan tanpa batas dalam pekerjaan dasn alokasi kekayaan. Harta hanya dikelola dengan segala cara, baik halal ataupun haram. (Gunawan, 2010)

Konsep harta dalam ekonomi Islam saat ini adalah perihal yang sangat penting. Hal ini sejalan dengan pesatnya pertumbuhan industri syariah, lembaga keuangan dan perbankan syariah. Untuk itu, pembahasan akan harta haruslah di bawah naungan syariah islamiyah yang tidak terlepas dari maqashid syariah, yang di dalamnya terdapat kemaslahatan yang diberikan Allah kepada manusia demi kebaikan hidup di dunia ataupun di akhirat. Hal ini menyiratkan bahwa 
Islam dengan perangkat syariahnya mengatur harta dan bagaimana pemeliharaan harta yang diinginkan oleh al-Syāri (Sang Pembuat Hukum; Allah SWT).

Harta dalam pandangan Islam pada hakikatnya adalah milik Allah, di mana Allah telah menyerahkannya kepada manusia untuk menguasai harta tersebut sehingga orang tersebut sah memiliki hartanya. Untuk itu, harta dalam pandangan Islam memiliki kedudukan yang penting.Dalam kaitannya dengan kegiatan bisnis ekonomi dan ritual ibadah, hartasangat diperhatikan sehingga di dalam maqashid syariah menjadikannyasalah satu poin penting, yaitu memelihara atau menjaga harta. Hal iniadalah maksud dan tujuan Allah dalam rangka memberikankemaslahatan kepada manusia untuk kiranya dijadikan sebagai pedoman didalam berbisnis dan bermuamalah.

Islam memandang harta sebagai sarana bagi manusia untuk mendekatkan diri kepada Khalik-Nya. Dengan keberadaan harta, manusia diharapkan memiliki sikap derma yang memperkokoh sifat kemanusiannya. Apabila sikap derma ini berkembang, maka akan mengantarkan manusia kepada derajat yang mulia, baik di sisi Allah maupun terhadap sesama manusia.

\section{Pembagian Harta}

Para ulama fikih membagi harta dari beberapa segi. Harta terdiri dari beberapa bagian, tiap-tiap bagian memiliki ciri khusus dan hukumnya tersendiri. Adapun pembagian harta antara lain:

1. Dilihat dari segi kebolehan pemanfaatannya menurut syara', dibagi:

a. Harta mutaqawwim, yaitu harta yang boleh dimanfaatkannya menurut syara'. Pengakuan syara' ini hanya akan berlaku dengan adanya syarat-syarat berikut: (1) harta tersebut dimiliki oleh pemilik berkenaan secarasah; (2) harta tersebut boleh dimanfaatkan dengan mengikuti hukum syara' (Ismail, 1995, p. 65). Misalnya, sapi halal dimakan oleh umat Islam. Akan tetapi, apabila sapi tersebut disembelih tidak menurut syara' (semisal dipukul), maka daging sapi tersebut tidak bisa dimanfaatkan karena cara penyembelihannya batal (tidak sah) menurut syara'. 
b. Harta ghairu mutaqawwim, yaitu harta yang tidak boleh dimanfaatkannya menurut ketentuan syara', baik jenisnya, cara memperolehnya, maupun cara penggunaannya. Misalnya, babi dan khamar termasuk harta ghairu mutaqawwimkarena jenisnya. Sepatu yang diperoleh dari hasil mencuri termasuk harta ghairu mutaqawwim karena cara memperolehnya yang haram. Uang disumbangkan untuk membangun tempat pelacuran termasuk harta ghairu mutaqawwimkarena penggunaannya.

2. Dilihat dari segi jenisnya, dibagi:

a. Harta manqul, yaitu harta yang dapat dipindahkan dari satu tempat ke tempat lain, baik tetap pada bentuk dan keadaan semula ataupun berubah bentuk dan keadaannya dengan perpindahan/perubahan tersebut. Harta dalam kategori ini mencakup uang, barang dagangan, macam-macam hewan, kendaraan, dan lainlain.

b. Harta ghairu manqul, yaitu harta yang tidak dapat dipindahkan dan dibawa dari satu tempat ke tempat lain. Misalnya, tanah dan bangunan yang ada di atasnya (Huda, 2011, pp. 18-19).

3. Dilihat dari segi pemanfaatannya, dibagi:

a. Harta isti'mali, yaitu harta yang apabila digunakan atau dimanfaatkan benda itu tetap utuh, sekalipun manfaatnya sudah banyak digunakan, seperti kebun, tempat tidur, rumah, sepatu, dan lain sebagainya.

b. Harta istihlaki, yaitu harta yang apabila dimanfaatkan berakibat akan menghabiskan harta itu, seperti sabun, makanan, dan lain sebagainya (Mardani, 2013, p. 63).

4. Dilihat dari segi ada/tidaknya harta sejenis di pasaran, dibagi:

a. Harta mitsli, yaitu harta yang jenisnya mudah didapat di pasaran (secara persis dari segi bentuk atau nilai). Harta mitsli terbagi atas empat bagian, meliputi: (1) harta yang ditakar, seperti gandum; (2) harta yang ditimbang, seperti besi; (3) harta yang dapat dihitung, seperti telur; dan (4) harta yang dijual dengan meter, seperti kain, papan, dan lain-lain.

b. b.Harta qimi, yaitu harta yang tidak ada jenis yang sama dalam satuannya di pasaran, atau ada jenisnya tetapi pada setiap unitnya berbeda dalam kualitasnya, 
seperti satuan pepohonan, logam mulia, dan alat-alat rumah tangga (Djuwaini, 2008, p. 19).

5. Dilihat dari status harta, dibagi:

a. Harta mamluk, yaitu harta yang telah dimiliki, baik milik perorangan atau milik badan hukum atau milik negara. Harta mamluk terbagi menjadi dua macam, yaitu: (1) harta perorangan yang bukan berpautan dengan hak bukan pemilik, seperti rumah yang dikontrakan; dan (2) harta pengkongsian antara dua pemilik yang berkaitan dengan hak yang bukan pemiliknya, seperti dua orang berkongsi memiliki sebuah pabrik dan lima buah mobil, salah satu mobilnya disewakan kepada orang lain.

b. Harta mubah, yaitu harta yang asalnya bukan milik seseorang, seperti mata air, binatang buruan, pohon-pohonan di hutan, dan lain-lain. Harta semacam ini boleh dimanfaatkan oleh setiap orang dengan syarat tidak merusak kelestarian alam.

c.Harta mahjur, yaitu harta yang ada larangan syara' untuk memilikinya, baik karena harta itu dijadikan harta wakaf maupun diperuntukkan untuk kepentingan umum. Harta ini tidak dapat dijualbelikan, diwariskan, dihibahkan, maupun dipindahtangankan 


\section{Daftar Pustaka}

Alis, S. (2019). Kepemilikan Harta. Ekonomi Syariah, 1(2), 80-100.

Gunawan, A. (2010). Kepemilikan Dalam Islam. Ekonomi Syariah, 1(2), 50-90.

Leli, M. (2019). Konsep Harta Dan Kepemilikan. Ekonomi Syariah, 1(2), 60-90.

Murlan, E. (2011). Konsep Kepemilikan Harta. EkonomiSyariah, 1(2), 100-140.

Sularno, M. (2013). Konsep Kepemilikan Dalam Islam. Ekonomi Syariah, 1(2), 100-130. 